\title{
A Research of The Relationship Between High School Students' Social Media Usage and Their Well-Being ${ }^{1}$ \\ Hilal Alkan², Büşra Doğan ${ }^{3}$
}

\section{ARTICLE INFO}

Article History:

Received 24.05.2018

Received in revised form

15.08.2018

Accepted

Availa ble online 01.10.2018

\begin{abstract}
This study aimed to assess whether or not the social media usage of high school students predicts levels of their well-being. Social Media Use Integration Scale is applied to students in order to measure the social media usage of students while Well-Being Scale is applied in order to measure their well-being. The study is conducted with 262 (142 female, 120 male) high school students studying in an educational institution in Uskudar district of Istanbul. As a result of the scale evaluations made, it was seen that Facebook usage did not predict Well-Being significantly. According to the results, the Facebook usage of high school students is low and it is not predictive of Well-Being.
\end{abstract}

(C) 2018 IJERE. All rights reserved

Keywords:

Social Media, Well-Being, High School Students

\section{INTRODUCTION}

The development of information technology has been developing very fast that has brought changes in many aspects of today's life. This development of technology and the sudden introduction of the internet into our lives, interpersonal interaction is experienced quickly and intensively, while at the same time, many people also brought the insensitive (Edwar, Agustin, and Fahmi, 2018).

With this desensitization, people's behavior develops in a different way, the state and movements are changing and people are referred to new searches, virtual environments, communication tools. With these tools that give time and space flexibility, space has been liberated from the natural constraints of the human body, and the distinction between remote and near has been lifted thanks to the connection of computer terminals and video monitors (Aydoğan, 2010).

Especially the Internet and Internet communication media are the biggest supporters of this process. Beginning in the 1970s, the rapidly increasing internet use after the 1990s, social networks, along with the widespread of websites have increased the number of the users, tow ards the 2000s is no longer valid social media adoption has become attract the attention of people from all sectors and to ensure that relevant It has come to the point. Individuals and communities that are able to communicate with each other more quickly and economically at low cost together with social networking netw orks can use these netw orks effect ively and effectively if needed (Babacan, Haşlak and Hira, 2011).

All things considered, social media is defined as a form of human communication that is based on mobile-based shares and discussions without time and space limitations. (Vural and Bat, 2010). In other words, social media is the most preferred digital medium in today's w orld where the internet tools and other people share and discuss their experiences and information in the electronic environment. (Gürsakal, 2009). In academic literature and in everyday life instead of the concept of social media, social netw ork, social w eb, social networking sites are also used concepts; however, to cover all of this area has a meaning that is more appropriate to use the concept of social media (Sayımer, 2008).

In addition to this, the usage of social media, which has become a habit of being used by the users of today's virtual world, has come to the position to respond to social demands of large masses from most cultures. The development of new communication media, the increasing interest in information communication technologies from all walks have led to a further increase in social media power. (Vural and

\footnotetext{
1 This study was presented orally at the IVth Symposium on Sciences in Alanya on May 3-4-5, 2018.

2 Corresponding e-mail: alknhilal@hotmail.com Hacettepe University ,orcid.org/0000-0002-1813-1004

${ }^{3}$ Corresponding e-mail: busra454@gmail.com Sakarya University
} 
Alkan,H. \& Doğan,B. (2018).A research of the relationship between high school students' social media usage and their well-being. International Journal of Educational Research Review, 3(4),97-102.

Bat, 2010). According to the "European Communication Monitor 2009" survey of 34 European countries on communication and public relations, the importance of social media applications will increase in the coming period (Yağmurlu, 2011).

We should also point out that besides the advantages of the Internet, many problems arise from misuse of the Internet, social media and the other social networks (Nartgun, Uylas, and Yerlikaya, 2016). The negative changes in the well-being are one of these problems. In this study, we tried to focus on the relationship between social media usage and well-being.

Generally, health was defined as the absence of symptoms before the 1940s. When we came to 1947, the World Health Organization developed a new definition in broader terms and defined health as "a state of complete well-being, not merely in the absence of illness and disability but in physical, mental and social aspects". (Fişek, 1985; Witmer and Sweeney,1992). According to Westgate (1996), the concept of well-being is a concept that is interested in investigating the functions of healthy people. In his view, the state of wellbeing is the process of self-examination that is related to the individual's physiological and psychological needs and planning his/her life to meet these needs (Owen, Çelik and Doğan, 2017). As you can see from the definitions, the scope of health has been expanded to include spiritual and social concepts. One aspect that draws attention here is that health is explained by "well-being" (Doğan, 2006).

The exact components of well-being are precisely still unknown, but it is a multidimensional concept that also has content such as autonomy, personal development, life purpose, good human rel ationships, and selfacceptance (Ryff and Keyes, 1995). Hettler (1984), known as the father of the concept of well-being, states that well-being is a process in which the individual makes choices for a successful existence (Korkut, 2004). The common thought of all theorists is that "goodness" is a way of life in which the individual plays an active role in determining his own well-being. For the individual to live fully in its environment and in its natural environment, it is the way in which the soul, the body, and the mind are opt imally healthy and wellbehaved (Dogan, 2006).

The usage of social media has become a part of our lives; this situation affects our psychological status, our behavior, our spiritual world, and therefore our well-being. When we associate our state of w ell-being with social media in relation to each other, the relationship and influence with our lives cannot be ignored.

The aim of this research is to determine the relationship between the well-being of social media usage of secondary school students.

The findings that will emerge as a result of the relationship between social media usage and well-being of secondary education students; will affect educators, their families, theories and contribute to the research area on what to pay attention to in this regard.

\section{METHOD}

\section{Research design}

In this study, the relational scanning model was selected. The relationship between the two variables is defined as the method used to determine the relationship between the variables and to estimate the possible outcomes and to measure the level of the relationship between the two or more variables using statistical tests.

\section{Universe and sample/ Participants}

The universe of the study is composed of secondary education students. The sample of the study is composed of students studying in high schools in Üsküdar district of Istanbul in the 2017-28 academic year.

The sample is easily determined by the sampling method. In an easy sample method, a sample is tried to be created by selecting easily accessible units. The selection of the sample is defined by the interviewer as selecting among individuals and volunteer participants who are in the right place at the right time. 
Alkan,H. \& Doğan,B. (2018).A research of the relationship betw een high school students' social media usage and their well-being. International Journal of Educational Research Review, 3(4),97-102.

Table 1. Distribution of sample group by gender

\begin{tabular}{lccc}
\hline Variables & $\mathrm{N}$ & $\%$ \\
& & & \\
\hline \multirow{2}{*}{ Gender } & Female & 142 & 54.2 \\
& Male & 120 & 45.8 \\
\hline
\end{tabular}

\section{Material}

Two measurement instruments were used to collect research data. The validity and reliability of the Turkish version of the "Social Media Use Integration Scale" that was done by Akın, Özbay, and Baykut (2015). The scale gives both subscales and total points. High scores indicate high lev els of social media use.

As a result of the confirmatory factor analysis, the two-dimensional model $w$ as w ell adapted $(x 2=74.92$, $\mathrm{SD}=31, \mathrm{RMSEA}=.076, \mathrm{NFI}=.93=\mathrm{NNFI} .94=\mathrm{CFI} .96=\mathrm{IFI} .96=$ GFI. 94, SRMR $=.049)$. SOCIAL MEDIA USE INTEGRATION SCALE Cronbach alpha internal consistency reliability coefficients were .87 for total scale, .87 for social integration and emotional connection subscale, and .71 for integration into social routines subscale.

The corrected item-total correlations ranged from .31 to .76 . Overall findings show that this scale had high validity and reliability scores.

The validity and reliability of the Turkish version of the "Flourishing Scale" that was done by Akın and Fidan (2012). High scores show a high level of well-being. There are no substances on the scale that are rated as adverse.

The results of the confirmatory factor analysis indicated that the model $w$ as $w$ ell fit $\left(x^{2}=48.80, s d=18\right.$, $\mathrm{p}=0.00011$, RMSEA $=.066, \mathrm{NFI}=.97, \mathrm{CFI}=.98, \mathrm{IFI}=.98, \mathrm{RFI}=.96, \mathrm{GFI}=.97$, and $\mathrm{SRMR}=.038$ ). Factor loadings ranged from .60 to .78 . The internal consistency coefficient of the scale was .83 and the corrected item-total correlations ranged from .47 to .67 . Overall findings demonstrated that this scale had high validity and reliability scores.

\section{Collection Of Data:}

Research data were collected by the researcher. The researchers applied the measurement tools to the Study Group. Volunteers participated in the study.

\section{Data Analyses}

The data were analyzed by correlation, unpaired samples, $t$-test.

\section{FINDINGS}

In this section, The findings of the research regarding the hypotheses/sub-objectives are included.

Table 2. Findings on the relationship between social media use and well-being of secondary education students

The main Hypothesis of the research was stated as "there will be a positive correlation between social media use of secondary education students and their well-being" The data obtained from the analysis applied to determine whether social media use is related to the welfare state is shown below' Table 2.'is also given. 
Alkan,H. \& Doğan,B. (2018).A research of the relationship betw een high school students' social media usage and their well-being. International Journal of Educational Research Review , 3(4),97-102.

\begin{tabular}{|c|c|c|c|}
\hline \multicolumn{4}{|c|}{ Correlations } \\
\hline & & Social Media & Well-Being \\
\hline \multirow[t]{3}{*}{ Social Media } & Pearson Correlation & 1 &,- 007 \\
\hline & Sig. (2-tailed) & & ,909 \\
\hline & $\mathbf{N}$ & 262 & 262 \\
\hline \multirow[t]{3}{*}{ Well-Being } & Pearson Correlation &,- 007 & 1 \\
\hline & Sig. (2-tailed) & ,909 & \\
\hline & $\mathbf{N}$ & 262 & 262 \\
\hline
\end{tabular}

As shown in the table, it was found that there was no significant correlation between social media usage and the well-being of secondary education students ( $p>05)$.

Table 3. T-test results according to the gender of social media usage of secondary education students

\begin{tabular}{lcccccc}
\hline Gender & $\mathrm{N}$ & $\mathrm{X}$ & $\mathrm{S}$ & $\mathrm{SD}$ & $\mathrm{t}$ & $\mathrm{p}$ \\
& & & & & & \\
\hline Female & 142 & 1,9444 &, 78239 & 260 &,- 823 &, 558 \\
Male & 120 & 2,0267 &, 83412 & & & \\
& & & & & & \\
\hline
\end{tabular}

As shown in the table, the usage of social media for secondary education students does not differ significantly from gender. $(p>) 05)$.

Table 4. T-test results according to the gender of the well-being of secondary school students

\begin{tabular}{lcccccc}
\hline Gender & $\mathrm{N}$ & $\mathrm{X}$ & $\mathrm{S}$ & $\mathrm{SD}$ & $\mathrm{t}$ & $\mathrm{p}$ \\
& & & & & & \\
\hline Female & 142 & 5,1347 & 1,15182 & 260 &, 319 &, 960 \\
Male & 120 & 5,0896 & 1,12298 & & & \\
& & & & & & \\
\hline
\end{tabular}

As show $\mathrm{n}$ in the table, the well-being cases of secondary school students do not differ significantly from gender. $(\mathrm{p}>) 05)$.

\section{RESULT, DISCUSSION, AND SUGGESTIONS}

The aim of this study is to investigate the relationship between social media usage and their well-being of secondary education students.

The findings obtained as a result of the research are as follows: 
Alkan,H. \& Doğan,B. (2018).A research of the relationship between high school students' social media usage and their well-being. International Journal of Educational Research Review, 3(4),97-102.

There was no significant relationship between social media usage and the well-being of secondary school students and social media usage and well-being and gender. According to this results, high school students do not use social media because it affects their well-being positively or social media usage does not increase their well-being. Consequently, more detailed research should be done to find out why high school students use social media.

Research shows that the usage of Facebooks by young people is decreasing. According to the data, in 2017 facebook lost $9.9 \%$ of its users in the U.S. between the ages of 12 and 17, IE about 1.4 million users. That's almost three times what it's supposed to be. Us users in this age range dropped to about 12.1 million at the end of the year. emarketer also announced that Facebook lost 2.8 million users under the age of 25 in the United States in 2017. (Perçin, 2018)

In this study, the questions of the Social Media Use Integration Scale are only Facebook, which is one of the limitations of our study.

In the study, it was observed that the Facebook usage rates of secondary education students decreased, as in previous studies. Therefore, a new scale can be developed that includes different social networking sites other than Facebook to measure the level of social media usage of secondary school students.

Contrary to the decrease in Facebook usages rates, the usage of social media is increasing in young people. Digital in 2017 Global Overview report that active social media users increased by $21 \%$, up 482 million versus 2015. (Kemp, 2017) Therefore, studies should be carried out to raise social aw areness, prevent social media addiction and abuse, use social media effective and efficient.

\section{REFERENCES}

Akın, A., \& Fidan, M. (2012). The validity and reliability of the Turkish version of the Flourishing Scale. Paper presented at the 3rd International Conference on New Trends in Education and their Implications (ICONTE2012), April, 26-28, Antalya, Turkey.

Akın, A., Özbay, A., \& Baykut, İ. (2015). Sosyal medya kullanımı ölçeğinin Türkçe formunun geçerliği ve güvenirliği. The Journal of International Social Research, 8(38), 628-633.

Aydoğan, F., (2010). İkinci medya çağında gözetim ile kamusal alan paradoksunda internet. İkinci medya çağında internet, der. F. Aydoğan, A. Akyüz, İstanbul: Alfa Yayınları.

Babacan, M. E., Haşlak, İ., \& Hira, İ. (2011). Sosyal medya ve arap baharı. Akademik İncelemeler Dergisi, 6(2).

Doğan, T. (2006). Üniversite öğrencilerinin iyilik halinin incelenmesi. Hacettepe Üniversitesi Ĕ̆gitim Fakültesi Dergisi, 30(30).

Doğan, T. (2006). Üniversite öğrencilerinin iyilik halinin "maneviyat" ve "serbest zaman" boyutlarının incelenmesi. Türk Psikolojik Danışma ve Rehberlik Dergisi, 3(26), 1-16.

Edwar, M, Agustin Diansari, R, Fahmi Winaw ati, N. (2018). The factors that affecting the product purchasing decision through online shopping by students of Surabaya State University. International Journal of Educational Research Review, 3 (4), 54-64. DOI: 10.24331/ijere.432350

Fişek, N. (1985). Halk sağlığına giriş. Ankara: H.Ü. Dünya Sağlık Örgütü Hizmet Araştırma ve Araştırıcı Yetiştirme Merkezi Yayını.

Gürsakal, N. (2009). Sosyal ă̆ analizi. Dora Yayınları, s. 21.

Hettler, W. (1984). Wellness: Encouraging a lifetime pursuit of excellence. Health Values: Achieving High-Level Wellness, 8, 13-17.

Kemp, S. (2017, 24 Ocak). Digital In 2017: Global overview. We are social. Web. 22 Mayıs 2018. 
Alkan,H. \& Doğan,B. (2018).A research of the relationship betw een high school students' social media usage and their well-being. International Journal of Educational Research Review , 3(4),97-102.

Korkut, F. (2004). Prevention and wellness. Eurasian Journal of Educational Research (EJER), (15).

Korkut, F., Çelik, N. D. \& Doğan, T. (2017). Üniversite öğrencilerinde iyilik halinin yordayıcısı olarak psikolojik sağlamlık. Electronic Journal of Social Sciences, 16(64).

Nartgun, S., Uylas, S. \& Yerlikaya, S. (2016). Analyzing the relationship between cyberbullying sensibility and cyber victimization levels of high school students. International Journal of Educational Research Review 1:18.

Perçin, F. (2018, 14 Şubat). Facebook genç kullanıcılarını kaybediyor. Dünya Halleri. Web. 22 Mayıs 2018.

Ryff, C. D. \& Keyes, C. L. M. (1995). The structure of psychological well-being revisited. Journal of Personality and Social Psychology, 69(4), 719-727. http://dx.doi. org/10.1037/0022-3514.69.4.719

Sayımer, İ. (2008). Sanal ortamda halkla ilişkiler. Beta Yayınları, s. 71.

Seyhan, B . (2014). Üniversite öğrencilerinde tanrı tasavvuru ve psikolojik iyi olma hali arasındaki ilişkiler. Cumhuriyet Üniversitesi İlahiyat Fakültesi Dergisi, 18 (1), 65-97. DOI: 10.18505/cuifd.254637

Vural, Z., \& Bat, M. (2010). Yeni bir iletişim ortamı olarak sosyal medya. Ege üniversitesi iletişim fakültesine yönelik bir araştırma. Journal of Yasar University, 5(20).

Westgate, C. E. (1996). Spiritual wellness and depression. Journal of Counseling and Development, 75: 26-35.

Witmer, J. M. \& Sweeney, T. J. (1992). A holistic model for wellness and prevention over the lifespan. Journal Of Counseling E, Development, 71, (2),140-148.

Yağmurlu, A. (2011). Kamu yönetiminde halkla ilişkiler ve sosyal medya. Selçuk Üniversitesi İletişim Fakültesi Akademik Dergisi, 7(1), 5-15. 